\title{
An experimental study on effect of dust on power loss in solar photovoltaic module
}

\author{
Athar Hussain ${ }^{1 *}$, Ankit Batra $^{2}$ and Rupendra Pachauri ${ }^{3}$
}

\begin{abstract}
In the present study, a detailed investigation on air dust particles effect on photovoltaic (PV) model performance has been carried out. The scanning electron microscope analysis of the collected dust samples was being carried out, and the obtained images were being analyzed in order to observe the character and topography of the dust sample particles. The data for dust samples of different weights with change in power loss in a PV module at three solar irradiations levels of 650,750 and $850 \mathrm{~W} / \mathrm{m}^{2}$ have been collected. In present study, the effect of environmental dust particles on power loss in PV module has been evaluated by measuring the electrical performance index such as voltage, current and power. The minimum power value of $3.88 \mathrm{~W}$ has been observed during the accumulation of rice husk on PV module.
\end{abstract}

Keywords: Renewable energy, Solar irradiation, Photovoltaic system, Dust samples, Rice husk, Fly ash, Badarpur sand, Brick powder

\section{Introduction}

In today's era of globalization, every work done has a hidden outcome of itself. The change in climate is one of the toughest challenges faced by today's world. The production of electricity is the main cause for industrial pollution which is not only causing threats to the environment but also affecting the amount of limited traditional energy sources, e.g., coal, petrol and diesel etc. This has led to the search of some alternative energy sources, called as renewable energy sources, e.g., solar and wind. Renewable sources are natural sources that can be replenished over a period of time, and the energy that comes from these sources is called as renewable energy (RE).

There are different forms of RE such as solar, wind, biofuel, geothermal and tides. RE supports in the power consumption $16 \%$ globally. Out of $16 \%$, biomass is used $10 \%$, hydroelectricity is used $3.4 \%$ and other $3 \%$ is from newer forms of RE such as modern biomass, geothermal, solar, wind and biofuels. RE has many advantages; some of them are: (1) inexhaustible, (2) clean, i.e., eco-friendly

\footnotetext{
*Correspondence: athariitr@gmail.com

${ }^{1}$ Civil Engineering Department, Ch. Brahm Prakash Government

Engineering College, Jaffarpur, New Delhi 110073, India

Full list of author information is available at the end of the article
}

in nature, (3) deployed mostly everywhere and without the expensive power lines, (4) require less maintenance than non RE source.

\section{Solar energy}

PV cells convert sunlight into electricity by an energy conversion process. In most of the cases of PV cells, photons (light energy) falls on the cells that results in exciting electrons in the atoms of a semiconductor material. Silicon is the main element for making PV systems. The energized electrons result in the generation of an electric voltage and current. PV systems have shown a great attention today because it is clean and secure utilization.

These types of systems give an opportunity to home owners by generating electricity in a reliable, clean and quiet way that can reduce future electricity costs and decrease dependency on grid power. Life of PV cells is very long. (In the USA, the first PV system installed-in 1954-is still operating today). The output voltage, current and power of PV system vary as the functions of solar irradiation.

Heat-absorbing modules are used by solar thermal collectors and a series of circulation tubes attached to heat water or buildings. Active solar thermal systems catch solar radiations to heat air of surroundings and/or water 
for industrial, commercial or domestic use. Solar concentration systems generally use mirrors. They usually arranged in a series of long and large round dish, parabolic troughs or a circle covered with a "power tower"to focus the reflected rays of sun on a heat-collecting element. The concentrated sunlight heats water or a fluid transferring heat such as molten salt used to generate steam, which is then used conventionally to rotate turbines and produce electricity.

Passive solar design is the creative use of windows, skylights and sun rooms, building site and orientation, and thermal construction materials to heat and light buildings, or to heat water, the natural way. In India and many other countries around the globe where availability of solar energy is huge, PV system has evolved as a big candidate to fulfill the energy demand. It also extends as a best alternative for clean (without any pollution) energy source, with about very less running and maintenance cost.

\section{Environmental impact on the performance of PV system}

The performance of PV systems is highly affected by internal and external factors such as the structural features, aging, radiation, shading, temperature, wind, pollution and cleanliness. Any type of climatic change causes changes in the solar radiations and in the ambient temperature, hence causing changes in the solar PV output performance. In this paper, effect of air dust particles on PV model is studied and analyzed with different dust samples and conditions.

\section{Dust}

Dust may be defined as crushed form minute particles having size less than $500 \mu \mathrm{m}$. Dust may come in the environment from various sources such as constructional sites, industries and dust storm. Dust consists of visible and invisible, floating and fallen particles of solid material.

\section{Literature review \\ Effect of dust on solar PV panel}

The degree of efficiency deterioration depends on the specific mass and size of dust particles deposition on PV module surface. As the mass of dust deposition increases, power output and the efficiency of the module decrease, and as the size becomes smaller, power output decreases as smaller particles block more radiation on PV module surface. The different pollutant depositions may include red soil, ash, sand, calcium carbonate, silica, etc. The presence of air pollution may significantly deteriorate the energy yield of PV panels; even after a short period of the panels' outdoor exposure (e.g., 2 months) without cleaning, it may cause a decrement of $6.5 \%$ in energy production approximately (Sarver et al. 2013).

In desert area, the accumulation of dust on PV panel surface is very high. The reduction in solar efficiency due to dust on PV panel is approximately $40 \%$. In this context, various PV system cleaning methods are adopted currently (Kumar and Chaurasia 2014). The analysis under this category of the environmental effects is the most frequent and problematic one as compared to others. Thus, this is faced on a regular basis throughout the year, unlike other conditions. Pollution basically, in respect to PV panel, is the accumulation of dust particles on the PV module surface. These particles may comprise of sand, ash, etc. in accordance with the vicinity in which the panel has been kept (Adinoyi and Said 2013). The experiment performed under this category contains analysis of the drop in solar irradiations due to dust. In Fig. 1, accumulation of dust on solar PV system is shown in GBU hostel itself.

Researchers (Rajput and Sudhakar 2013) investigated experimentally the effect of deposited dust particles on PV modules and provided a concept on electrical performances. The study concentrated on parameters such as radiation availability, efficient operating strategies, design and sizing of these systems. It was concluded that dust significantly reduces the efficiency of solar PV module. Researchers also carried out a performance analysis on the environmental effects on PV modules (Darwish 2013). The research inferred that the mean of the daily energy loss along a year caused by dust deposited on PV module surface is around $4.4 \%$. In long periods without rain, daily energy losses can be higher than 20\%. Dust particles differ in phase, sort, chemical and physical properties depending on many environmental conditions. Air, humidity and temperature in addition to wind speed play a significant role in defining isolated dust and how it will collect on the PV cell.

Another study being conducted by researchers inferred that dust is the lesser acknowledged factor that significantly influences the performance of the PV installations

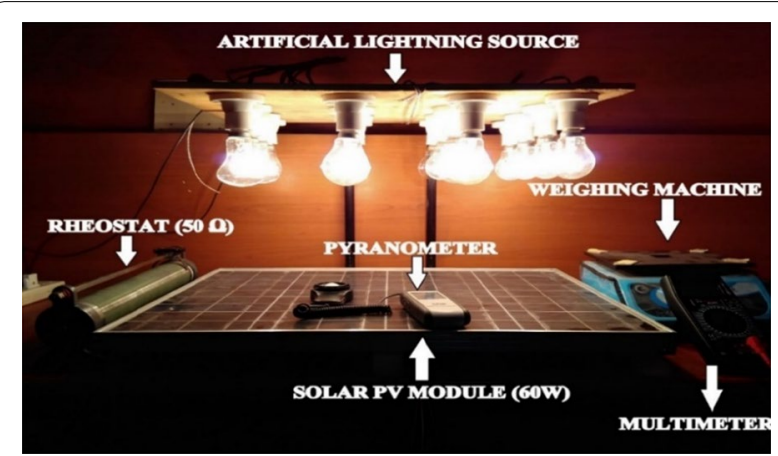

Fig. 1 Experimental setup used in present study 
(Mani and Pillai 2010). They appraised on the current status of research in studying the impact of dust on PV system performance and identified challenges to further pertinent research. However, some researchers proposed and discussed the effect of dust on the transparent cover of solar collectors (Elminir 2006). The reduction in glass normal transmittance depends strongly on the dust deposition density in conjunction with plate tilt angle, as well as on the orientation of the surface with respect to the dominant wind direction. The evolutions of the power variation with increasing PV cell pollution. It has been found that the slope of best straight line passing through the data points of the solar cell installed at a $45^{\circ}$ angle facing south suggests a decrease in the output power of about $17.4 \%$ per month.

Researchers carried out a study to determine the influence of dust in the aggravated environment of the Greek capital, Athens, and considered that the dust effects are site-specific (Kaldellis and Kokala 2010). Similarly some researchers carried out fundamental studies on dust fouling effects on PV module glass cover (Said and Walwil 2014). It was found that the spectral transmittance reduction was around $35 \%$ and the overall transmittance was around $20 \%$. It was also observed that the dust particles accumulated were generally spherical in shape. Researchers gave a concept on effect of dust deposition on the performance of multicrystalline PV modules based on experimental measurements (Kazem et al. 2014). The authors investigated the dust effect on the PV module (multicrystalline) performance and the degradation of PV performance due to the deposition of different pollutants and accumulation.

The authors (Mekhilef et al. 2012) have correlated between thickness of dust collected on PV module and difference in efficiencies in composite climate. They inferred that there is a significant reduction in PV module output, near $10-20 \%$, when heavy layers of dust are accumulated. They also reported that a small amount of dust on solar PV module covers has a negligible effect on the sunlight transmission to the silicon PV module. Researchers conducted studies on the effect of various influential parameters on the efficiency and performance of PV cells. However, none has taken all these three parameters into account simultaneously (Mekhilef et al. 2012).

Researchers studied the influence of dirt accumulation on performance of PV modules and analyzed the effects of particles on solar module performance (Sulaiman 2014). The study reported that external resistance could reduce PV performance by up to $85 \%$. This study also concluded that water droplet from rain would not affect significantly the performance of PV modules. An investigation being carried out reported that out of $100 \%$ energy coming from sun approximately 30\% of the energy is either reflected back or is absorbed by clouds, oceans and land masses (Panjwani and Narejo 2014). It has also been reported that the solar energy which actually strikes the solar cell is subjected to loss in absorption/reflection of energy; the approximate losses are about $15-30 \%$ of the energy obtained.

The experiment-based solar tracker is presented and passively activated by aluminum/steel bimetallic strips. The efficiency is up to $23 \%$ over fixed solar panels. The results show the excellent agreement with the computer model (Clifford and Eastwood 2004). A design, modeling and testing of an active single-axis solar tracker are presented. The smart tracker system operates at different modes to provide flexibility to accommodate different weather conditions by using light-dependent resister (LDR). Moreover, an experimental analysis shows an agreement with the performance of MATLAB/Simulink model (Chin et al. 2011; Chin 2012).

The authors (Shukla et al. 2015) presented the experimental study on $5 \mathrm{~W}$ amorphous and polycrystalline PV modules. The performance assessment is carried out in terms of voltage and current. An attempt has been made to evaluate thermal, electrical and exergy of PV module. The parameters such as module temperature, heat loss, voltage, current and fill factor are considered for extensive investigation (Sudhakar and Srivastava 2014).

A comprehensive review on analysis of energy and exergy of building integrated PV module is assessed with the electrical performance (Shukla et al. 2016a). The authors (Kumar and Sudhakar 2015) elaborated annual performance in terms of various types of power losses and performance ratio. The obtained results of the PV plant are compared with the PV-SYST and PV-GIS software tools.

The authors (Shukla et al. 2016b) designed an isolated rooftop solar PV system for a hostel building, and performance evaluation is carried out using simulation. The cost estimation including cabling, maintenance, controller and man power is done.

Most of the researchers carried out the studies on effect of dust accumulation on the surface of PV modules. It is proved that power decreased up to $50 \%$ due to dust accumulation for a 6-month study. Also the authors investigated the performance of a solar collector drops progressively as dust is accumulated on its surface. The authors selected rooftop PV panels to evaluate the PV performance for a certain time period, and the influence of different dust deposition densities on the energy yield and the economic performance of the small power station is estimated.

On the basis of studies being carried out by the researchers, it can be inferred that the performance of 
PV module is highly affected by the deposition of red soil, followed by limestone and finally by the fly ash samples. Considering these facts in view, a study was being planned with the objective to study the impact of various dust particles on the performance of solar PV module and to identify the relationship of the particle size with respect to the solar PV performance.

\section{Dust cleaning methods on solar PV panel surface}

Dust cleaning on PV surface is a very important research scope to explore more advanced cleaning systems with efficient methods. Some of important cleaning methods are discussed as follows.

PV module cleaning technology provided improved efficiency and protected the solar cell. The authors summarized all the dust removal methods such as natural removal of dusts, mechanical removal dusts, self-cleaning nano-film and electrostatic removal of dusts (He et al. 2011). For maximum power generation, a linear piezoelectric actuator-based technology for solar panel cleaning is adopted in industy environment. A wiper is fixed with the actuator for linear motion to remove the dust layer away effectively from the solar module surface. This cleaning technology is lightweight and compact in size (Lu et al. 2013).

Reducing the cost of the solar panel cleaning is a key research issue for feasibility of solar plant. The authors focused on optimizing the cleaning methods for solar plant at semidesert climate outdoor conditions. Different cleaning methods are used, and according to obtained results, the most effective cleaning method is based on water and a brush cleaning. The obtained results are validated the concept as average efficiency of $98.8 \%$ in rainy periods and 97.2\% in dry seasons (Garcia et al. 2014).

The authors developed an innovative receiver tube study for monitoring the performance of solar panel cleaning methods. Five distinguish cleaning methods have been applied and concluded that the receiver tube is the most effective method. This method is traditional in comparison with the rest of the tested methods. The authors (Kawamoto and Shibata 2015) have been developed an improved cleaning system that uses electrostatic force to remove sand from solar panel surface. The designed cleaning system is demonstrated and found that more than $90 \%$ of the adhering sand is repelled from the PV module surface. The performance of the system was improved, even when the deposition of sand on the panel is extremely high. The proved technology is expected to enhance efficiency of MW solar power plants located in desert areas.

The authors (Mondal and Bansal 2015) have developed an electromechanical-based robotic arm system for solar PV module surface cleaning. The system has been analyzed and optimized for high effectivity. The developed system does not affect the actual performance of PV system, since it is not coupled with the PV panels. As the tests were conducted on $50 \mathrm{~W}$ PV panels, the efficiency enhancement is found. Dust, dirt and bird droppings are the major causes of reduction in PV system performance. A comprehensive overview is presented on dust issues, and the recent developments made on automated cleaning system for solar PV modules (Mondal and Bansal 2015).

\section{Materials and methods} Apparatus description

For the investigation of dust fouling a PV module, the experimental system required various equipments to obtain the results as (1) a $60 \mathrm{~W}$ polycrystalline PV module (TATA green power-model no. 1260) has been placed under a mounted artificial lightening source comprising total 16 numbers electric lamps of $100 \mathrm{~W}$ each. An artificial lightening setup is used to avoid inconsistency in solar radiation. (2) Multimeter (MASTECH, M3900) and a resistance load of $50 \Omega$. (3) Solar irradiation meter (DT-1307). (4) Dust samples: (a) Badarpur sand 1, (b) Badarpur sand 2, (c) fly ash, (d) rice husk, (e) chalk powder, (f) brick powder, (g) sand. (5) Weighing machine to determine the dust quantity. The experimental setup is shown in Fig. 1.

The specifications of solar PV module and measurement instruments which are used in the present study are summarized in Tables 1 and 2.

The following performance parameters were measured for each dust sample in experimental setup environment,

1. Dust sample weight (gm.)

2. Voltage $(\mathrm{V})$

3. Current (A)

4. Power (W)

5. Power loss (\%)

6. Power transferred (\%)

\section{Dust sample analysis}

In present study, the dust samples were collected from different sources and the SEM image analysis was carried out. The obtained images have been analyzed in order to observe the nature of the dust particles and topography of the dust samples. The dust samples as shown in Fig. 2a-g and taken for the present study are (1) Badarpur sand 1, (2) Badarpur sand 2, (3) fly ash, (4) rice husk, (5) chalk powder, (6) brick powder, (7) sand.

These dust samples have been taken for the present study in India; because solar is growing exponentially, still there are many places which have to be covered in future such as constructional sites, agricultural land and 
Table 1 PV module (TATA green power) specifications at STC

\begin{tabular}{ll}
\hline Parameters & Specifications \\
\hline Peak power $\left(P_{\max }\right)$ & $60 \mathrm{~W}$ \\
Voltage $(\mathrm{Vm})$ & $22.0 \mathrm{~V}$ \\
Current $\left(I_{\mathrm{m}}\right)$ & $2.72 \mathrm{~A}$ \\
Minimum by pass diode & $15 \mathrm{~A}$ \\
Maximum series fuse & $15 \mathrm{~A}$ \\
Cell operating temperature & $25^{\circ} \mathrm{C}$ \\
Solar irradiation & $1000 \mathrm{~W} / \mathrm{m}^{2}$ \\
\hline
\end{tabular}

many more. These dust samples such as Badarpur sand 1 , Badarpur sand 2 and brick powder are mainly found at constructional sites while fly ash is mainly found in coal industries. The rice husk is mainly found at places where rice is being cleaned from dhan (rice bran), and chalk powder and sand are very common forms of dust that can be found at any educational institutes, playgrounds, etc.

All the dust samples are analyzed under SEM to obtain size and bonding density of the dust particles. The SEM images for all types dust samples are shown in Fig. 3a-g.

The experimental study has been carried out by using the $60 \mathrm{~W}$ PV module mounted on a stand. Dust sample was being spread uniformly using a flour strainer with sieve size approximately $25-30 \mathrm{~mm}$ over the module surface, and module is set up under the artificial lightning source. The data for dust samples of different weights with change in power loss of solar module at three radiations values of 650,750 and $850 \mathrm{~W} / \mathrm{m}^{2}$ have been collected and summarized. A multilayer flour strainer is used to spread the dust samples uniformly, and an extensive investigation of dust effect on the PV modules is carried out. The experimental setup design and the measurement of performance results in terms of current, voltage and power are taken in real experimental environment.

\section{Results and discussion}

The study was carried out using different values of voltage and current at solar PV module with different dust samples having different weights at three radiation values of 650,750 and $850 \mathrm{~W} / \mathrm{m}^{2}$. Effect of particle size on power output of solar PV module has also been analyzed. The power output of solar PV module is obtained with seven different dust samples having different weights by observing voltage and current measurements. The PV module output power has been measured three times, and the average of all three values of voltage and current has been reported in the study.

A comparative study of total seven dust samples has been carried out, and the results are summarized in Tables 3 and 4 at three radiation levels of 650, 750 and $850 \mathrm{~W} / \mathrm{m}^{2}$ with different weights. Accumulation of dust particles on solar PV systems blocks the sunlight and hence reduces its power to a large extent. It is assumed that "solar is the nearest future"; hence, dust from different fields such as constructional sites, agricultural land and industrial areas will affect solar systems in coming time. Perusal of the data from Tables 3 and 4 indicates the power reduction due to accumulation of dust on PV module.

Data summarized in Table 3 indicate that in case of Badarpur sand 1 of $50 \mathrm{gm}$ weight sample the maximum power losses of 59.31, 60.70 and $62.10 \%$ have been observed at radiation levels of 650,750 and $850 \mathrm{~W} / \mathrm{m}^{2}$, respectively. Similarly, while using a 25 gm of fly ash sample the maximum power loss of $42.05,43.33$ and $43.36 \%$

Table 2 Specifications of measuring instruments

\begin{tabular}{|c|c|c|}
\hline Instrument & Rating and range & Application \\
\hline Multimeter (MASTECH, M3900) & $\begin{array}{l}\text { DC voltage: } 200 \mathrm{mV} / 2 / 20 / 200 / 1000 \mathrm{~V} \pm 0.5 \% \\
\text { DC current: } 20 \mu \mathrm{A} \pm 2.0 \%, 200 \mu / 2 \mathrm{~m} / 20 \mathrm{~mA} \pm 0.8 \% \\
200 \mathrm{~m} / 2 \mathrm{~A} \pm 1.2 \%, 10 \mathrm{~A} \pm 2.0 \% \\
\text { Resistance: } 200 / 2 \mathrm{k} / 20 \mathrm{k} / 200 \mathrm{k} / 2 \mathrm{M} \Omega \pm 0.5 \%, 20 \mathrm{M} \Omega \pm 1.0 \%\end{array}$ & $\begin{array}{l}\text { PV module output voltage and current measure- } \\
\text { ment }\end{array}$ \\
\hline Solar irradiation meter (DT-1307) & $\begin{array}{l}\text { Resolution: } 1 \mathrm{~W} / \mathrm{m}^{2} \\
\text { Sampling time: approx. } 0.25 \mathrm{~s} \\
\text { Range: } 1999 \mathrm{~W} / \mathrm{m}^{2} \\
\text { Accuracy: } \pm 5 \% \\
\text { Size }(\mathrm{mm}): 160(\mathrm{~L})^{*} 63(\mathrm{~W})^{*} 28(\mathrm{H}) \\
\text { Weight: about } 250 \mathrm{~g} \\
\text { Operating temperature: } 40^{\circ} \mathrm{C}\end{array}$ & Solar irradiation intensity measurement \\
\hline Rheostat load & $\begin{array}{l}\text { Resistive loads with adjustable node } \\
\text { Resistance: } 50 \Omega \\
\text { Current: } 0.71 \mathrm{~A} \text { (maximum) } \\
\text { Power: } 35.5 \mathrm{~W} \\
\text { Single-tube single-wire wound }\end{array}$ & Restive load for voltage and current measurement \\
\hline
\end{tabular}



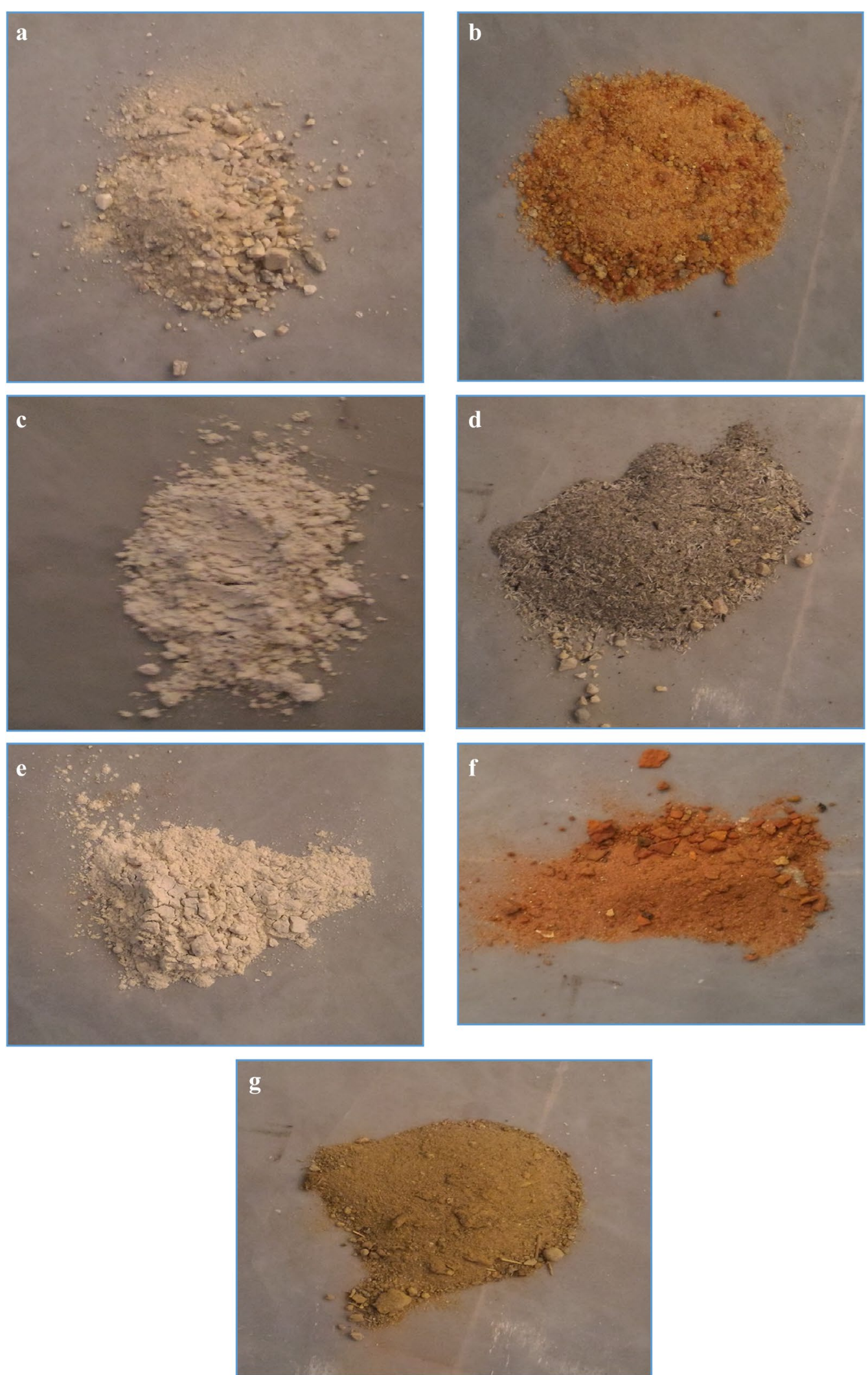

Fig. 2 Dust samples for current study a Badarpur sand 1, b Badarpur sand 2, c fly ash, $\mathbf{d}$ rice husk, e chalk powder, $\mathbf{f}$ brick powder and $\mathbf{g}$ sand 

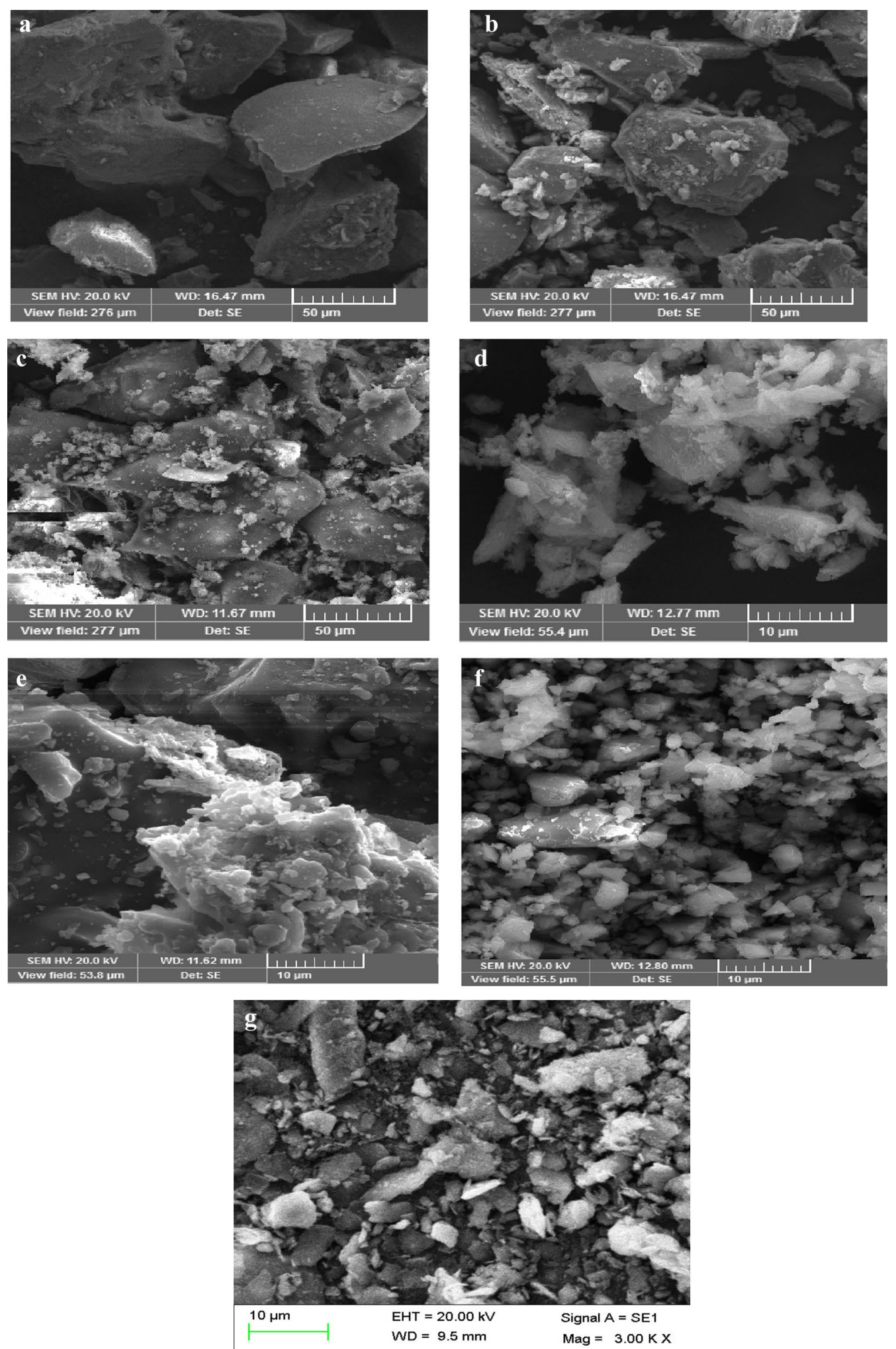

Fig. 3 SEM images for a Badarpur sand $1(50 \mu \mathrm{m})$, b Badarpur sand $2(50 \mu \mathrm{m})$, c fly ash $(50 \mu \mathrm{m})$, d rice husk (10 $\mu \mathrm{m})$, e chalk powder $(10 \mu \mathrm{m}), \mathbf{f}$ brick powder $(10 \mu \mathrm{m})$ and $\mathbf{g}$ sand $(10 \mu \mathrm{m})$ 


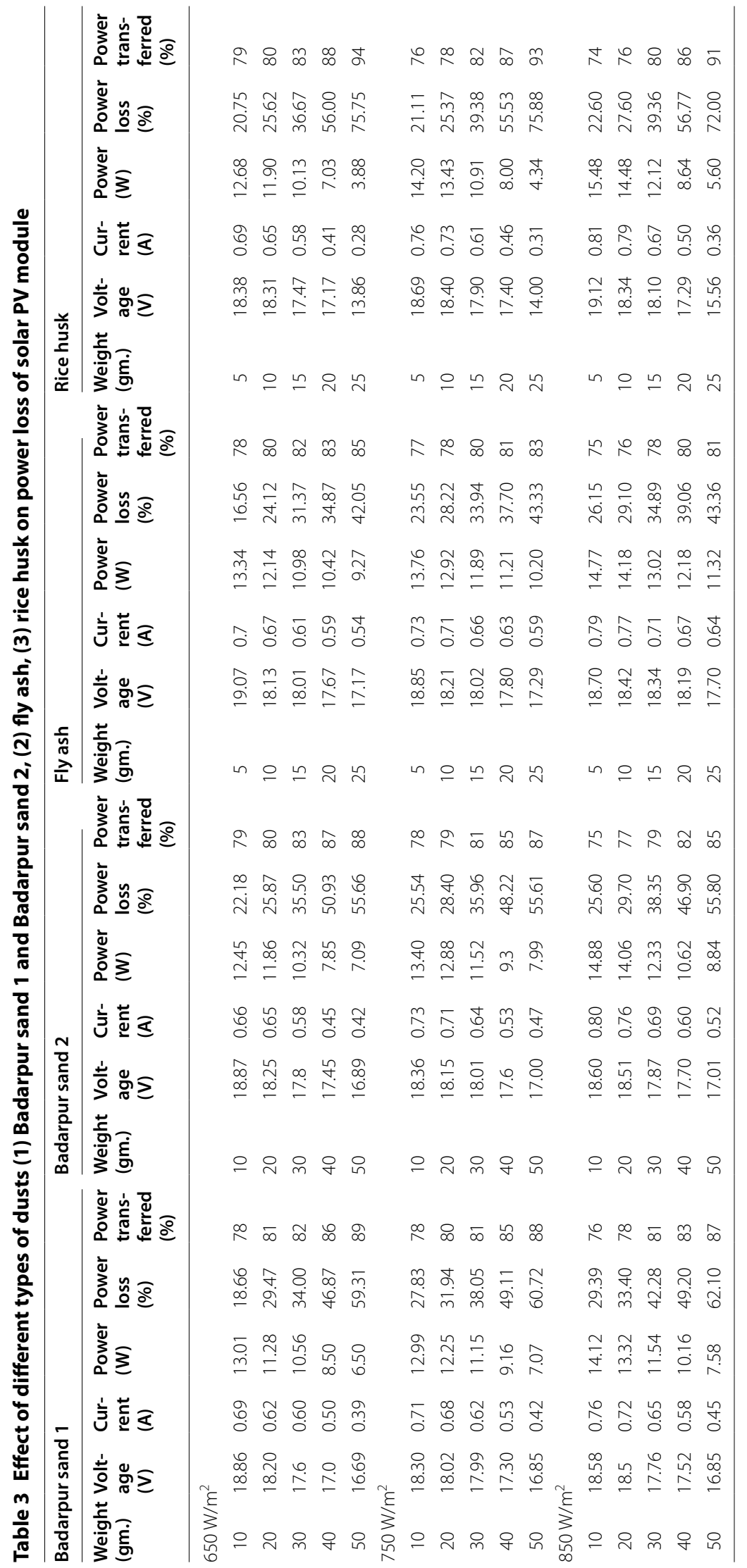




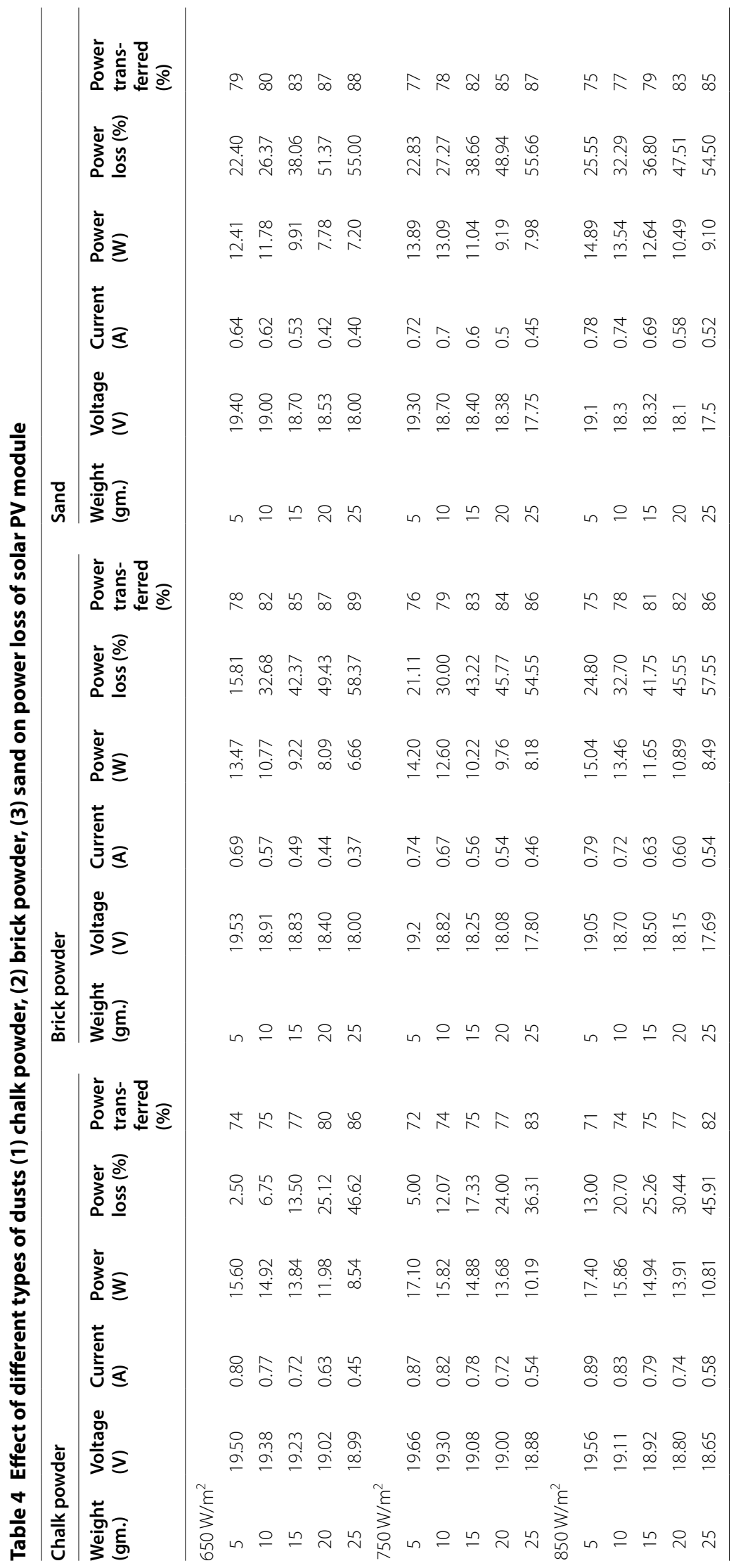


have been observed at radiation levels of 650,750 and $850 \mathrm{~W} / \mathrm{m}^{2}$, respectively. However, in case of $25 \mathrm{~g}$ of rice husk sample the maximum power losses of $75.75,75.88$ and $72 \%$ have been observed under radiation levels of 650,750 and $850 \mathrm{~W} / \mathrm{m}^{2}$, respectively. Also the maximum power loss in chalk powder sample of $25 \mathrm{~g}$ is found to be $46.62,36.31$ and $45.41 \%$ at measured radiation levels of 650,750 and $850 \mathrm{~W} / \mathrm{m}^{2}$, respectively. In case of $25 \mathrm{~g}$ brick powder sample taken for study, the maximum power losses are observed to $58.37,54.55$ and $57.55 \%$ at radiation levels of 650,750 and $850 \mathrm{~W} / \mathrm{m}^{2}$, respectively. However, perusal from data summarized in Tables 3 and 4 indicates that the power loss is found to be maximum using rice husk at different radiation levels 650 , 750 and $850 \mathrm{~W} / \mathrm{m}^{2}$, respectively. This may be due to the high molecular density of rice husk, which increases the power loss.

It is concluded that a uniform layer of $10 \mathrm{~g}$ accumulated on solar PV module can reduce its power up to $25 \%$ and when module is accumulated uniformly with $50 \mathrm{~g}$ of dust then power is reduced approximately 55-63\%. Also from Table 3, it can also be inferred that if a uniform layer of $5 \mathrm{~g}$ of dust is accumulated on solar PV module, it can reduce its power approximately $15 \%$. Also when module is accumulated uniformly with $25 \mathrm{~g}$ of dust, then power is reduced approximately $45-55 \%$. The data in Table 3 for rice husk indicate that a uniform layer of $5 \mathrm{~g}$ dust accumulation on solar PV module can reduce its power up to $20 \%$, and at a dust accumulation of $50 \mathrm{~g}$ on PV module, the power is reduced approximately $70 \%$.

Perusing the data from Table 4, it is concluded that an accumulation of uniform dust layer of $5 \mathrm{gm}$ on solar PV module can reduce its power up to $13 \%$, and when $50 \mathrm{~g}$ of the dust is accumulated on PV module uniformly, the power is found to be reduced approximately $50 \%$.

The maximum power loss in case of $25 \mathrm{~g}$ sand sample is found to be $55,55.66$ and $54.50 \%$ at measured radiation levels of 650,750 and $850 \mathrm{~W} / \mathrm{m}^{2}$, respectively. Perusal of the data from Table 3 indicates that there is no significant change in power losses under different sample weight and different radiation conditions. However, the maximum power loss is observed in rice husk sample under all conditions. Also from the SEM analysis as shown in Fig. $3 a-f$, the rice husk sample is found to be the smallest particle size of all the samples taken for the study. Therefore, it may be inferred that size of the particle is inversely proportional to the power loss in solar panels and modules. It indicates that particle size has a significant effect on the power loss in solar panels. The existance of all the dust samples is typical at same place, but mostly two-three types of dust samples can be found in industrial and/or rural areas; sometimes, it depends on the seasonal basis also (specially for rice husk type of dust).

\section{Graphical analysis of showing power-to-weight response of all considered dust samples}

The data obtained in the present study for the different types of dust samples at different weights have been taken. Based on these dust samples, the power loss has been evaluated for the solar PV module at three radiation levels of 650,750 and $850 \mathrm{~W} / \mathrm{m}^{2}$. The obtained results have been analyzed and are shown in Fig. $4 \mathrm{a}-\mathrm{g}$.

The data depicted in Fig. 4a-g indicate that the smaller size particle occupies more surface area of the PV module and hence blocks more solar radiation. In the present study, through graphical representation this theory proves to be true. However, the minimum and maximum power being obtained in present study using different forms of dust is summarized in Table 5 .

From Table 4, for the $10 \mathrm{~g}$ weight samples of Badarpur sand 1 and Badarpur sand 2 taken for study, the minimum power is observed as $6.5 \mathrm{~W}$ and $7.09 \mathrm{~W}$ and maximum power is found to be $14.12 \mathrm{~W}$ and $14.88 \mathrm{~W}$, respectively. Also in case of $5 \mathrm{~g}$ rice husk sample the minimum and maximum power is observed as $3.88 \mathrm{~W}$ and $15.48 \mathrm{~W}$, respectively. However, in case of fly ash and chalk powder the minimum and maximum power obtained is $9.27,8.54$ and $14.77,17.40 \mathrm{~W}$, respectively, at a sample weight of $5 \mathrm{~g}$. In case of brick powder sample of $5 \mathrm{~g}$, the minimum power value is found to be $6.66 \mathrm{~W}$ and maximum power value as observed is $15.04 \mathrm{~W}$. Also in case of $5 \mathrm{~g}$ sand sample, the minimum and maximum power values as obtained are 7.20 and $14.89 \mathrm{~W}$, respectively. From the data summarized in Table 4, it is apparent that minimum power value of $3.88 \mathrm{~W}$ is obtained during the accumulation of rice husk on PV module. The SEM image also indicates that the rice husk particle size of $10 \mu \mathrm{m}$ is the smallest of all types of dust forms used in the present study.

\section{Conclusion}

A comparative study of total seven dust samples has been carried out at three radiation levels of 650, 750 and $850 \mathrm{~W} / \mathrm{m}^{2}$ with different dust samples weights. Due to accumulation of dust particles on the surface of solar PV systems, and output power is reduced to a large extent. It is concluded that a small layer of dust itself reduces PV system efficiency to a large extent. The minimum power value of $3.88 \mathrm{~W}$ is obtained during the accumulation of rice husk on the solar PV module. From the SEM analysis and obtained power values, it is confirmed that the smallest particle blocks more sunlight and thus reduces 

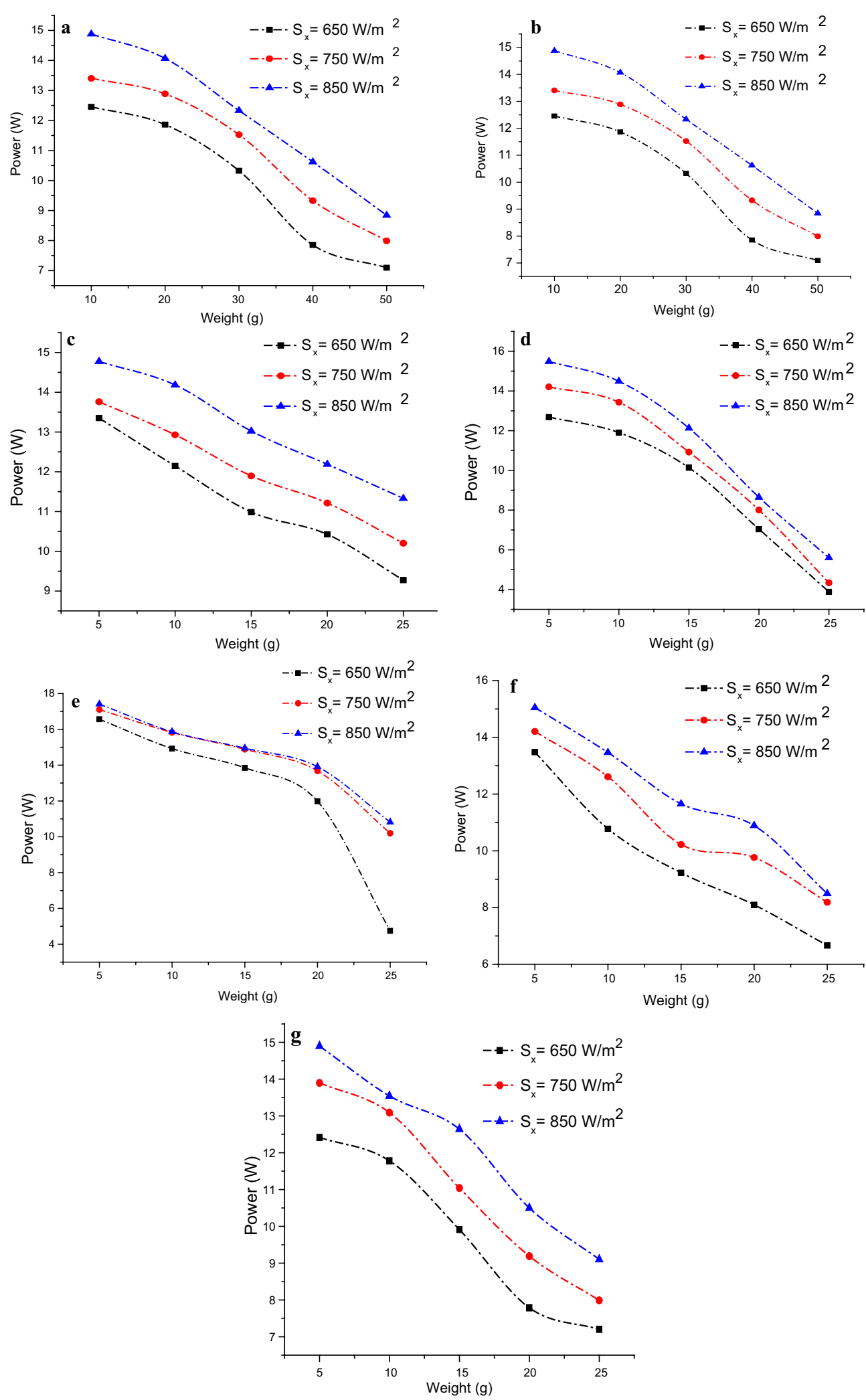

Fig. 4 Power-to-weight response of different forms of dust used on solar PV module in the present study a Badarpur sand 1, b Badarpur sand 2, c fly ash, d rice husk, e chalk powder, $\mathbf{f}$ brick powder, $\mathbf{g}$ sand 
Table 5 Minimum and maximum power obtained using different forms of dust samples

\begin{tabular}{lllll}
\hline Dust sample type & Weight $(\mathbf{g})$ & Minimum power $(\mathbf{W})$ & Weight (g) & Maximum power (W) \\
\hline Badarpur sand 1 & 10 & 6.50 & 50 & 14.12 \\
Badarpur sand 2 & 10 & 7.09 & 50 & 14.88 \\
Fly ash & 5 & 9.27 & 25 & 14.77 \\
Rice husk & 5 & 3.88 & 25 & 15.48 \\
Chalk powder & 5 & 8.54 & 25 & 17.40 \\
Brick powder & 5 & 6.66 & 25 & 15.04 \\
Sand & 5 & 7.20 & 25 & 14.89 \\
\hline
\end{tabular}

the efficiency of solar panels and modules. It can also be concluded that in desert areas where probability of sunlight is maximum and where a solar array plan can be established, due to the accumulation of dust the efficiency of solar modules and panels in terms of power can be reduced up to $60 \%$.

\section{Abbreviations}

PV: Photovoltaic; SEM: Scanning electron microscope.

\section{Authors' contributions}

$A B$ has carried out the research work under the guidance of $A H$ and RKP. AH is main author of this manuscript. All authors read and approved the final manuscript.

\section{Author details}

${ }^{1}$ Civil Engineering Department, Ch. Brahm Prakash Government Engineering College, Jaffarpur, New Delhi 110073, India. ${ }^{2}$ Civil Engineering Department, Environmental Engineering Section, School of Engineering, Gauatm Buddha University, Greater Noida, U.P. 201312, India. ${ }^{3}$ Department of Electronics Instrumentation and Control Engineering, School of Engineering Studies, University of Petroleum and Energy Studies, Dehradun, Uttarakhand 248007, India.

\section{Acknowledgements}

The authors of this manuscript are thankful to Biomed Central (The Publisher of Renewables: Wind, Water and Solar) for waving off the article processing charges (APC) for this manuscript.

\section{Competing interests}

The authors declare that they have no competing interests.

\section{Availability of data and materials}

The dataset(s) supporting the conclusions of this article is (are) included within the article.

\section{Funding}

It is to declare that no funding for research has been received from any fund ing agency for design of study, collection, analysis and interpretation of data and in writing the manuscript.

\section{Publisher's Note}

Springer Nature remains neutral with regard to jurisdictional claims in published maps and institutional affiliations.

Received: 15 June 2017 Accepted: 4 December 2017

Published online: 21 December 2017

\section{References}

Adinoyi, M. J., \& Said, S. A. M. (2013). Effect of dust accumulation on the power outputs of solar photovoltaic modules. Renewable Energy, 60, 633-636.

Chin, C. S. (2012). Model-based simulation of an intelligent microprocessorbased standalone solar tracking system. In V. Katsikis (Ed.), MATLAB-A fundamental tool for scientific computing and engineering applications (pp. 251-278). Rijeka, Croatia: InTech.

Chin, C. S., Babu, A., \& McBride, W. (2011). Design, modeling and testing of a standalone single axis active solar tracker using MATLAB/Simulink. Renewable Energy, 36(11), 3075-3090.

Clifford, M. J., \& Eastwood, D. (2004). The design of a new passive solar tracker. Solar Energy, 77(3), 269-280.

Darwish, Z. A. (2013). Impact of some environmental variables with dust on solar photovoltaic: Review and research. International Journal of Energy and Environment, 7(4), 152-159.

Elminir, H. K. (2006). Effect of dust on the transparent cover of solar collectors. Energy Conversion and Management, 47, 3192-3203.

Garcia, A. F., Rodrigo, L. A., Arcos, L. M., Aguiar, R., \& Payes, J. M. (2014). Study of different cleaning methods for solar reflectors used in CSP plants. Energy Procedia, 49, 80-89.

He, G., Zhou, C., \& Li, Z. (2011). Review of self-cleaning method for solar cell array. Procedia Engineering, 16, 640-645.

Kaldellis, J. K., \& Kokala, A. (2010). Quantifying the decrease of the photovoltaic panels energy yield due to phenomena of natural air pollution disposal. Energy, 35, 4862-4869.

Kawamoto, H., \& Shibata, T. (2015). Electrostatic cleaning system for removal of sand from solar panels. Journal of Electrostatics, 73, 65-70.

Kazem, A. A., Chaichan, M. T., \& Kazem, H. A. (2014). Dust effect on photovoltaic utilization in Iraq: Review article. Renewable and Sustainable Energy Reviews, 37, 734-749.

Kumar, S., \& Chaurasia, P. B. L. (2014). Experimental study on the effect of dust deposition on solar photovoltaic panel in Jaipur (Rajasthan). International Journal of Science and Research, 3(6), 1690-1693.

Kumar, B. S., \& Sudhakar, K. (2015). Performance evaluation of 10 MW grid connected solar photovoltaic power plant in India. Energy Reports, 1, 184-192.

Lu, X., Zhang, Q., \& Hu, J. (2013). A linear piezoelectric actuator based solar panel cleaning system. Energy, 60, 401-406.

Mani, M., \& Pillai, R. (2010). Impact of dust on solar photovoltaic (PV) performance: Research status, challenges and recommendations. Renewable and Sustainable Energy Reviews, 14(9), 3124-3131.

Mekhilef, S., Saidur, R., \& Kamlisarvestani, M. (2012). Effect of Dust. Humidity and air velocity on efficiency of photovoltaic cells, renewable and sustainable energy reviews, 16, 2920-2925.

Mondal, A. K., \& Bansal, K. (2015a). Structural analysis of solar panel cleaning robotic arm. Current Science, 108(6), 1047-1052.

Mondal, A. K., \& Bansal, K. (2015b). A brief history and future aspects in automatic cleaning systems for solar photovoltaic panels. Advanced Robotics, 29, 515-524.

Panjwani, M. K., \& Narejo, G. B. (2014). Effect of humidity on the efficiency of solar cell (photovoltaic). International Journal of Engineering Research and General Science, 2, 499-503. 
Rajput, D. S., \& Sudhakar, K. (2013). Effect of dust on performance of solar PV panel. International Journal of ChemTech Research, 5(2), 1083-1086.

Said, S. A. M., \& Walwil, H. M. (2014). Fundamental studies on dust fouling effects on PV module performance. Solar Energy, 107, 328-337.

Sarver, T., Al-Qaraghuli, A., \& Kazmerski, L. L. (2013). A comprehensive review of impact of dust on the use of solar energy: History, investigations, results, literature and mitigation approaches. Renewable and Sustainable Energy Reviews, 22, 698-733.

Shukla, A. K., Sudhakar, K., \& Baredar, P. (2016a). Exergetic assessment of BIPV module using parametric and photonic energy methods: A review. Energy Buildings, 119, 62-73.
Shukla, A. K., Sudhakar, K., \& Baredar, P. (2016b). Design, simulation and economic analysis of standalone roof top solar PV system in India. Solar Energy, 136, 437-449

Shukla, K. N., Sudhakar, K., \& Rangnekar, S. (2015). A comparative study of exergetic performance of amorphous and polycrystalline solar PV modules. International Journal of Exergy, 17(4), 433-455.

Sudhakar, K., \& Srivastava, T. (2014). Energy and exergy analysis of 36 W solar photovoltaic module. International Journal of Ambient Energy, 35, 51-57.

Sulaiman, S. A. (2014). Influence of dirt accumulation on performance of PV panels. Energy Proceedia, 50, 50-56.

\section{Submit your manuscript to a SpringerOpen ${ }^{\circ}$ journal and benefit from:}

- Convenient online submission

- Rigorous peer review

- Open access: articles freely available online

- High visibility within the field

- Retaining the copyright to your article

Submit your next manuscript at springeropen.com 